\title{
Pembelajaran Fisika Berbasis Android dengan Program Adobe Flash CS 6 untuk Meningkatkan Kemampuan Berpikir Kritis dan Hasil Belajar Siswa SMA IT Granada Samarinda
}

\author{
Eka Yuliana*, Lambang Subagiyo ${ }^{2}$, dan Zulkarnaen ${ }^{3}$ \\ ${ }^{1^{*}}$ Program Studi Pendidikan Fisika, FKIP, Universitas Mulawarman \\ *E-mail: 541592eka@gmail.com
}

\begin{abstract}
Abstrak
Penelitian ini bertujuan untuk mengetahui penggunaan media pembelajaran berbasis android dengan program Adobe Flash CS 6 terhadap kemampuan berpikir kritis dan hasil belajar fisika kelas X. Jenis penelitian kali ini menggunakan pendekatan deskriptif. Subjek dalam penelitian ini adalah siswa kelas X SMA IT Granada Samarinda dengan jumlah sampel sebanyak 29 siswa pada kelas X IPA A. Pengumpulan data menggunakan teknik tes berupa 5 butir soal essai untuk mengetahui kemampuan berpikir kritis dan hasil belajar siswa yaitu berupa pretest dan posttest. Hasil penelitian menunjukkan bahwa penggunaan pembelajaranberbasis android dapat meningkatkan kemampuan berpikir kritis dan hasil belajar pada materi impuls dan momentum. Hal tersebut dapat dibuktikan dari meningkatnya kemampuan berpikir kritis siswa dan hasil belajar siswa dari kondisi awal (pretest) yaitu 27,9 kategori tidak kritis dan kurang sekali menjadi 72,3 pada kategori kritis dan baik pada kondisi akhir posttes sehingga diperoleh peningkatan dengan nilai gain 0,64 berada dalam kategori sedang.
\end{abstract}

Kata kunci: Pembelajaran berbasis android, hasil belajar, kemampuan berpikir kritis.

\begin{abstract}
This Research aims to know theusage of Android-based learning media with Adobe Flash CS 6 program against the critical thinking and learning outcomes of $X$-grade physics. This type of research uses a descriptiveapproach. The subject in this study is a grade $x$ student of IT Granada Samarinda with a sample number of 29 students in the class X IPA A. Data collection using a test technique in the form of 5 rounds of Essai to know the ability of critical thinking and student learning outcomes are the form of pretests and posttest. The results showed that using Android-based learning can improve the ability of critical thinking and learning outcomes on impulses and momentum. It can be proved from the increase of students 'critical thinking ability and learning outcomes from the initial condition (pretests) IE 27.9 category is not critical and less once to 72.3 in the critical category and good at the final condition posttes so that the increase with the gain value of 0.64 is in category medium
\end{abstract}

Keywords: Android-based learning, learning outcomes, critical thinking ability

Article History: Received: 21 Juli 2020

Accepted: 5 Agustus 2020
Revised : 19 Agustus 2020

Published: 20 November 2020

How to cite: Yuliana, Eka., Subagiyo, L., dan Zulkarnaen.(2020). Pembelajaran Fisika Berbasis Android dengan Program Adobe Flash CS 6 untuk Meningkatkan Kemampuan Berpikir Kritis dan Hasil Belajar Siswa SMA IT Granada Samarinda, 1(2). pp. 105 - 114 . Retrieved from http://jurnal.fkip.unmul.ac.id/index.php/JLPF

Copyright (C) November 2020, Jurnal Literasi Pendidikan Fisika 


\section{PENDAHULUAN}

Pembelajaran adalah proses interaksi timbal balik siswa dengan pendidik dan sumber belajar pada suatu lingkungan belajar. Pembelajaran merupakan usaha sengaja, terarah dan bertujuan agar orang lain dapat memperoleh pengalaman yang bermakna (BSNP, 2006). Kemajuan teknologi berpengaruh terhadap pembelajaran dalam hal penggunaan media pembelajaran di sekolah-sekolah dan lembaga pendidikan lainnya, ditengarai dapat meningkatkan hasil pembelajaran. Pembelajaran berbasis teknologi informasi dan komunikasi akan berjalan efektif jika peran pengajar dalam pembelajaran adalah sebagai fasilitator pembelajaran atau memberikan kemudahan pembelajar untuk belajar bukan hanya sebagai pemberi informasi (Hanum, 2013). Proses pembelajaran dengan memanfaatkan teknologi informasi dan komunikasi merupakan bimbingan dari pengajar untuk memfasilitasi pembelajaran pembelajar yang efektif. Pemakaian media pembelajaran dalam proses belajar mengajar dapat membangkitkan minat dan keinginan yang baru, membangkitkan motivasi dan rangsangan kegiatan belajar, bahkan membawa pengaruh-pengaruh psikologis terhadap siswa.

Sumber-sumber belajar selain guru disebut sebagai penyalur atau penghubung pesan ajar yang diadakan dan diciptakan secara terencana oleh para guru atau pendidik, biasanya dikenal sebagai media pembelajaran. Dengan demikian, komponen-komponen komunikasi pembelajaran menjadi komunikator, komunikan, pesan dan media.

Kata media berasal Bahasa Latin, yakni "medius" yang secara harfiah berarti 'tengah','perantara' atau 'pengantar'. Di bahasa Arab media disebut 'wasail' bentuk jama' dari 'wasilah', yakni sinonim "alwast" yang artinya juga 'tengah'. Kata 'tengah' itu sendiri berarti berada di antara dua sisi, maka disebut juga sebagai 'perantara' (wasilah) atau yang mengantarai kedua sisi tersebut (Yudhi, 2013). Berdasarkan pernyataan diatas media dapat disebut juga sebagai pengantar atau penghubung, yaitu yang mengantarkan atau menghubungkan atau menyalurkan sesuatu hal dari satu sisi ke sisi yang lain. Lebih lanjut menurut Bovee dalam (Ena, 2011), Media adalah sebuah alat yang mempunyai fungsi menyampaikan pesan.

Perkembangan ilmu pengetahuan dan teknologi yang sangat pesat saat ini menyebabkan hampir semua aktivitas manusia dapat dikendalikan oleh aplikasi IImu Pengetahuan dan Teknologi (IPTEK). Dengan semakin berkembangnya ilmu pengetahuan dan teknologi maka diperlukan suatu usaha yang dapat mempermudah mengetahui ilmu-ilmu tersebut. Salah satu bentuk dari pengembangan media pembelajaran adalah pemanfaatan teknologi informasi dan komunikasi dalam bidang pendidikan. Bentuk dari pemanfaatan teknologi informasi dan komunikasi tersebut adalah mobile learning (m-learning), salah satu bagian dari electronic learning (e-learning). $M$ learning merupakan media pembelajaran dengan menggunakan perangkat bergerak seperti handphone, PDA, laptop, dan tablet PC (Darmayoga, Lasmawan, Marhaeni, 2013).

Hasil belajar mempunyai hubungan yang erat dengan belajar itu sendiri. Untuk mengetahui sampai mana perubahan yang terjadi pada diri sendiri baik itu perubahan tingkah laku dan kecakapan dapat dilihat dari hasil belajarnya. Secara umum untuk mengetahui hasil belajar siswa dapat diklasifikasikan ke dalam tiga ranah hasil belajar, ranah kognitif, ranah afektif dan ranah psikomotorik. Jadi hasil belajar dapat dikatakan sebagai pengetahuan yang dikuasai oleh siswa sebagai hasil dari kemampuan penyerapan pengetahuan dalam proses belajar mengajar baik secara perorangan maupun secara kelompok yang diintegrasikan ke dalam pelajaran (Pertiwi, 2016).

Hasil belajar dapat dikatakan sebagai hasil yang diperoleh dari suatu interaksi serta setelah melalui kegiatan pembelajaran. Guru akan mengakhiri suatu kegiatan belajar dengan evaluasi hasil belajar. Hasil belajar merupakan proses dari setiap individu untuk memperoleh suatu perubahan perilaku yang relatif tetap. Keberhasilan siswa dalam proses belajar dapat dilihat dari tercapainya tujuan pembelajaran yang telah ditetapkan oleh guru sebelumnya. Hasil belajar menjadi salah satu tolak ukur 
Pembelajaran Fisika Berbasis...

keberhasilan guru dalam melakukan proses pembelajaran di kelas. Hal ini terlihat dari apa yang telah dicapai siswa, dan kemampuan siswa dalam memahami dan menguasai konsep serta materi yang telah diajarkan oleh guru.

Berdasarkan uraian di atas, maka dalam penelitian ini yang dimaksud hasil belajar fisika siswa adalah pengetahuan yang dicapai siswa pada mata pelajaran fisika setelah melalui proses pengajaran di sekolah dari hasil test atau ujian yang diberikan setelah melalui proses belajar pada akhir materi. Asumsinya adalah pengetahuan yang diajar oleh guru pada mata pelajaran fisika dapat diserap secara optimal oleh siswa sehingga hasil belajar siswa dapat menggambarkan hasil pengajaran.

Keterampilan berpikir kritis dapat dikembangkan melalui Student-Centered Learning. Dalam pembelajaran ini, siswa akan berhubungan pengetahuan mereka dengan kehidupan sehari-hari mereka. Kemampuan berpikir kritis pada siswa sendiri dapat dilatih dengan menggunakan media pembelajaran yang mampu menstimulus siswa dalam menggunakan argumen atau sekedar menjawab pertanyaan. Media yang dirasa mampu membantu siswa dan guru dalam proses pembelajaran fisika adalah media pembelajaran berbasis mobile learning.

Kemampuan berpikir kritis merupakan pemikiran yang bersifat selalu ingin tahu terhadap informasi yang ada untuk mencapai suatu pemahaman yang mendalam. Kemampuan berpikir kritis menurut Facione dalam (Yustyan dkk., 2015) meliputi interpretation, analysis, inferensi, evaluation, explanation, dan self-regulation. Dalam taksonomi Bloom kemampuan berpikir dapat dikategorikan dari yang nyata ke abstrak yaitu pengetahuan, pemahaman, penerapan, analisis, sintesis, evaluasi.

Menurut (Fisher, 2001) berpikir kritis adalah mode berpikir mengenal hal, substansi atau masalah apa saja dimana si pemikir meningkatkan kualitas pemikirannya dengan menangani secara terampil struktur-struktur yang melekat dalam pemikiran dan menerapkan standar-standar intelektual padanya.

Berpikir kritis mempunyai makna yaitu kekuatan berpkir yang harus dibangun pada siswa sehingga menjadi suatu watak atau kepribadian yang terpatri dalam kehidupan siswa untuk memecahakan segala persoalan hidupnya. Keterampilan berpikir kritis sangat penting bagi siswa karena dengan keterampilan ini siswa mampu bersikap rasional dan memilih alternatif pilihan yang terbaik bagi dirinya.

Siswa yang memiliki keterampilan berpikir kritis akan selalu bertanya pada diri dalam setiap menghadapi segala persoalan untuk menentukan yang terbaik bagi dirinya. Demikian juga jika siswa yang memiliki keterampilan berpikir kritis akan terpatri dalam watak dan kepribadiannya terimplementasi dalam segala aspek kehidupannya.

Mobile learning merupakan media pembelajaran dengan menggunakan perangkat bergerak sehingga menawarkan kemudahan dalam mengakses materi pembelajaran dari mana saja dan kapan saja (Astra, 2012). Perlu disadari juga bahwa mobile learning adalah salah satu kemajuan dalam pengembangan teknologi informasi dan komunikasi (TIK). Selain itu mobile learning juga menjadi pembelajaran baru yang memberikan perhatian kepada mobilitas siswa, dengan hal tersebut siswa dapat belajar tanpa rasa tertekan karena lokasi belajar yang dibatasi secara fisik.

Adobe flash merupakan salah satu jenis aplikasi yang tergolong multimedia karena memiliki kombinasi teks grafik, animasi, audio dan video dalam satu teknologi seperti komputer. Adobe flash dapat dimanfaatkan dalam bidang pendidikan yaitu untuk membuat media pembelajaran. Adobe flash merupakan program yang digunakan untuk mengembangkan multimedia pembelajaran interaktif (MPI) karena mendukung untuk pembuatan animasi, gambar, teks, dan pemprogaman (Nurtantio dan Syarif, 2013).

Pembelajaran efektif dan fungsional dapat diperoleh dengan memanfaatkan fungsi media. Namun kenyataanya hampir di setiap sekolah menengah belum diterapkan media pembelajaran, sehingga materi yang harus disampaikan dengan contoh yang real belum tersampaikan dengan baik hanya sekedar penjelasan berbasis ceramah. (Febrianto,Rais, Nurmila, 2017)

Pada dunia pendidikan, penggunaan media 
Pembelajaran Fisika Berbasis...

pembelajaran berbasis flash dapat dikatakan belum maksimal karena keterbatasan kemampuan guru dalam mengikuti perkembangan teknologi. Berdasarkan data Persatuan Guru Republik Indonesia (PGRI) tahun 2014, dari 1,3 juta guru peserta uji kompetensi, hanya $30 \%$ yang mampu mengoperasikan komputer (Mulya, 2015). Konsultan Education Sector Analytical and Capacity Development Parthership (ACDP) Totok Amin Soefijanto (Linggasari, 2015), mengatakan salah satu penghambat dalam pemanfaatan teknologi dalam pembelajaran adalah karena kurangnya pelatihan bagi guru.

Pemilihan media animasi berbasis adobe flash dalam penelitian ini karena media ini memiliki kelebihan yaitu mampu meningkatkan hasil belajar siswa dan animasi ini juga memiliki kemampuan untuk dapat memaparkan sesuatu yang rumit atau kompleks dibandingkan pemaparan hanya dengan gambar atau katakata saja. Dengan kemampuan tersebut, maka animasi ini dapat digunakan untuk menjelaskan suatu materi yang secara nyata tidak dapat dilihat oleh mata, dengan cara melakukan visualisasi maka materi pelajaran yang dijelaskan dapat tergambarkan.

Adobe Flash Profesional perangkat lunak CS 6 adalah lingkungan authoring kuat untuk menciptakan animasi dan konten multimedia. Desain pengalaman mendalam interaktif yang menyajikan secara konsisten di desktop dan beberapa perangkat, termasuk tablet, telepon pintar, dan televisi. Penggunaan adobe flash diharapkan dapat membantu siswa menerima materi dengan baik. Siswa tidak hanya mendengarkan penjelasan dari guru saja siswa juga dapat melihat materi yang disampaikan dalam bentuk media yang dimuat semenarik mungkin. Dengan adanya media ini diharapkan siswa menjadi senang mengikuti pelajaran dan berminat mempelajari pelajaran IPA (Amalia, 2016).

Berdasarkan latar belakang diatas, maka dapat dijadikan landasan penulis untuk melakukan penelitian dengan judul "Pembelajaran Fisika Berbasis Android dengan Program Adobe Flash CS 6 untuk Meningkatkan Kemampuan Berpikir Kritis dan Hasil Belajar Siswa SMA IT Granada
Samarinda" Diharapkan dengan menerapkan pembelajaran berbasis android dengan pemanfaatan handphone secara tidak sadar siswa belajar sehingga diharapkan selain kesenangan juga didapatkan pengetahuan dan pemahaman materi pelajaran.

\section{METODE}

Jenis penelitian ini jenis penelitian yang digunakan adalah penelitian kuantitatif. Metode yang dilakukan menggunakan metode eksperimen semu (Quasy experiment). Desain penelitian yang digunakan adalah One-Groupe Pretest-Posttest Design. Pada desain ini terdapat pretest, sebelum diberi perlakuan. Dengan demikian hasil perlakuan dapat diketahui lebih akurat, karena dapat membandingkan dengan keadaan sebelum diberi perlakuan. Setelah diberi perlakuan selama 3 kali pertemuan, sampel diberi posttest dengan instrument soal yang mengacu pada indikator berpikir kritis.

Penelitian ini dilaksanakan di SMA IT Granada Samarinda tahun ajaran 2019/2020. Penelitian ini dilakukan pada siswa kelas X IPA A SMA IT Granada Samarinda. Waktu pelaksanaan penelitian ini dilakukan pada bulan Februari 2020. Dalam penelitian ini teknik pengumpulan data yang digunakan adalah tes tertulis berupa pretest dan posttest yang dilakukan pada akhir pembelajaran impuls dan momentum. Soal pretest dan posttest berbentuk essai (uraian) sebanyak 5 soal, yang mengacu pada indikator kemampuan berpikir kritis yaitu Elementary Clarification, Basic Support, Inference, Advance Clarification dan Strategy and Tactic. Teknik analisis data yang digunakan pada penelitian ini yaitu analisis $\mathrm{N}$-Gain untuk mengetahui peningkatan pada pretest dan posttest. Pengujian hipotesis menggunakan uji-t independent untuk mengetahui ada tidaknya pengaruh yang dilihat dari perbedaan hasil pretest dan posttest sebelum dan sesudah diterapkan pembelajaran berbasis android dengan program Adobe Flash CS 6. Sebelum dilakukan uji-t terlebih dahulu dilakukan uji normalitas untuk mengetahui data yang diperoleh apakah berdistribusi normal atau tidak dengan menggunakan SPSS 23 for windows. 
Pembelajaran Fisika Berbasis...

\section{HASIL DAN PEMBAHASAN}

\section{HASIL}

Hasil rata-rata siswa sebelum penerapan pembelajaran dengan media berbasis android (pretest), siswa memperoleh nilai dengan ratarata 27,9 dengan deviasi standar 17,6 . Hasil pretest nilai terendah yang diperoleh adalah 10 dan nilai tertinggi adalah 65 dari nilai maksimum 100.

Tabel 1. Hasil Rata-rata Pretest Siswa

\begin{tabular}{cccccc}
\hline \multicolumn{5}{c}{ Descriptive Statistics } \\
& N & $\begin{array}{c}\text { Mini } \\
\text { mum }\end{array}$ & $\begin{array}{c}\text { Maxi } \\
\text { mum }\end{array}$ & Mean & $\begin{array}{c}\text { Std. } \\
\text { Deviation }\end{array}$ \\
\hline $\begin{array}{c}\text { Pre } \\
\text { test }\end{array}$ & 29 & 10 & 65 & 27,9 & 17,6 \\
\hline
\end{tabular}

Data analisis hasil belajar siswa (pretest) dapat digolongkan dalam kategori penilaian hasil belajar siswa sebagai berikut.

Tabel 2. Persentase Penilaian Kategori Hasil Belajar Siswa (Pretest)

\begin{tabular}{cccc}
\hline Nilai & Kategori & $\begin{array}{c}\text { Jumlah } \\
\text { Siswa }\end{array}$ & $\begin{array}{c}\text { Persentase } \\
(\%)\end{array}$ \\
\hline $80 \leq x \leq 100$ & $\begin{array}{c}\text { Baik } \\
\text { Sekali }\end{array}$ & 0 & 0 \\
\hline $70 \leq x<80$ & Baik & 0 & 0 \\
\hline $60 \leq x<70$ & Cukup & 4 & $13,8 \%$ \\
\hline $50 \leq x<60$ & Kurang & 1 & $3,4 \%$ \\
\hline $0 \leq x<50$ & $\begin{array}{c}\text { Kurang } \\
\text { Sekali }\end{array}$ & 24 & $82,8 \%$ \\
\hline
\end{tabular}

Berdasarkan tabel tersebut, diperoleh data hasil belajar pada pretest siswa mendapatkan hasil pada kategori kurang sekali sebanyak 26 siswa dengan persentase $82,8 \%$. Hal ini menunjukkan pada saat pretest sebelum menggunakan media pembelajaran berbasis android hasil belajar siswa secara keseluruhan masih kurang sekali.

Data analisis hasil belajar siswa (pretest) dapat digolongkan dalam kategori penilaian berpikir kritis sebagai berikut:

Tabel 3. Persentase Penilaian Kategori Berpikir Kritis Siswa (Pretest)

\begin{tabular}{cccc}
\hline Nilai & Kategori & $\begin{array}{c}\text { Jumlah } \\
\text { Siswa }\end{array}$ & $\begin{array}{c}\text { Persentase } \\
(\%)\end{array}$ \\
\hline $81 \leq \mathrm{A} \leq 100$ & $\begin{array}{c}\text { Sangat } \\
\text { Tinggi }\end{array}$ & 0 & 0 \\
\hline $66 \leq \mathrm{B}<81$ & Kritis & 0 & 0 \\
\hline $56 \leq \mathrm{C}<66$ & Cukup & 5 & $17,2 \%$ \\
\hline $41 \leq \mathrm{D}<56$ & Kurang & 3 & $10,3 \%$ \\
\hline
\end{tabular}

\begin{tabular}{llll}
\hline & Kritis & & \\
\hline $0 \leq \mathrm{E}<41$ & Tidak & 21 & $72,5 \%$ \\
& Kritis & 21 & \\
\hline
\end{tabular}

Nilai rata-rata posttest siswa kelas X IPA A SMA IT Granada Samarinda adalah 72,3 dengan KKM sebesar 73. Hasil posttest dan rata-rata yang telah didapatkan tersebut kemudian dikategorikan berdasarkan kualifikasi hasil belajar menurut (Sudjana, 2013), yang disajikan dalam tabel berikut.

Tabel 4. Persentase Penilaian Kategori Hasil Belajar Siswa (Posttest)

\begin{tabular}{clcc} 
Nilai & Kategori & $\begin{array}{c}\text { Jumlah } \\
\text { Siswa }\end{array}$ & $\begin{array}{c}\text { Persentase } \\
(\%)\end{array}$ \\
\hline $80 \leq x \leq 100$ & $\begin{array}{l}\text { Baik } \\
\text { Sekali }\end{array}$ & 13 & 44,8 \\
$70 \leq x<80$ & Baik & 6 & 20,7 \\
\hline $60 \leq x<70$ & Cukup & 3 & $10,4 \%$ \\
\hline $50 \leq x<60$ & Kurang & 2 & $6,9 \%$ \\
\hline $0 \leq x<50$ & $\begin{array}{l}\text { Kurang } \\
\text { Sekali }\end{array}$ & 5 & $17,2 \%$ \\
& & \\
\hline
\end{tabular}

Data analisis hasil belajar siswa (posttest) dapat digolongkan dalam kategori penilaian berpikir kritis sebagai berikut:

Tabel 5. Persentase Penilaian Kategori Berpikir Kritis Siswa (Posttest)

\begin{tabular}{clcc}
\hline Nilai & Kategori & $\begin{array}{c}\text { Jumlah } \\
\text { Siswa }\end{array}$ & $\begin{array}{c}\text { Persentase } \\
(\%)\end{array}$ \\
\hline $81 \leq \mathrm{A} \leq 100$ & $\begin{array}{l}\text { Sangat } \\
\text { Tinggi }\end{array}$ & 11 & $38,0 \%$ \\
\hline $66 \leq \mathrm{B}<81$ & Kritis & 8 & $27,6 \%$ \\
\hline $56 \leq \mathrm{C}<66$ & Cukup & 4 & $13,8 \%$ \\
\hline $41 \leq \mathrm{D}<56$ & $\begin{array}{l}\text { Kurang } \\
\text { Kritis }\end{array}$ & 3 & $10,3 \%$ \\
\hline $0 \leq \mathrm{E}<41$ & $\begin{array}{l}\text { Tidak } \\
\text { Kritis }\end{array}$ & 3 & $10,3 \%$ \\
\hline
\end{tabular}

Perolehan N-Gain dari rata-rata pretest dan posttest adalah 0,64 yang lebih dari 0,3 dan kurang dari 0,7 sehingga peningkatan hasil belajar siswa termasuk dalam kategori sedang dengan deviasi standar 3,6.

Tabel 6. Persentase Penilaian Kategori Berpikir Kritis Siswa (Pretest)

\begin{tabular}{cccccccr} 
Pretest & Posttest & & \multicolumn{1}{c}{$\begin{array}{c}N- \\
\text { SD } \\
\text { Gain }\end{array}$} & Kriteria \\
\cline { 5 - 7 } $\begin{array}{c}\text { Rata- } \\
\text { rata }\end{array}$ & SD & $\begin{array}{c}\text { Rata- } \\
\text { rata }\end{array}$ & SD & & & \\
\hline 27,9 & 17,6 & 72,4 & 22,7 & 0,64 & 3,6 & Sedang \\
\hline
\end{tabular}

Uji normalitas yang digunakan adalah uji 
Shapiro Wilk dengan bantuan software SPSS 23.0 for Windows. Data dapat dikategorikan terdistribusi dengan normal apabila $p$-value > 0,05 , sebaliknya jika $p$-value $<0,05$ maka data dikatakan tidak terdistribusi dengan normal. Berikut adalah hasil uji normalitas data pretest dan posttest:

Tabel 7 Hasil Uji Normalitas Data Pretest-Posttest

\begin{tabular}{lccc}
\hline & $\begin{array}{c}\text { Shapiro-Wilk } \\
\text { Statistic }\end{array}$ & N & Sig. \\
\hline Pretest & 1.192 & 29 & .117 \\
\hline Posttest & .709 & 29 & .697 \\
\hline
\end{tabular}

Berdasarkan tabel tersebut, diperoleh data uji normalitas pada saat pretest adalah 0,117 lebih besar dari distribusi normal yaitu 0,05 dan uji normalitas pada saat posttest adalah 0,697 lebih besar dari syarat terdistribusi normal yaitu 0,05 . Hal ini menunjukkan bahwa pada saat pretest dan posttest data yang diperoleh berdistribusi normal. Setelah terbukti kedua sampel pretest dan posttest terdistribusi secara normal, maka digunakan uji independent $t$ test.

Tabel 8 Nilai Hasil Uji-t

\begin{tabular}{lr}
\hline \multicolumn{2}{c}{ Test Statistic $^{\text {a }}$ Pretest-Postest } \\
\hline t hitung & -8.334 \\
Asymp. Sig. (2-tailed) & .000 \\
\hline
\end{tabular}

\section{PEMBAHASAN}

Penelitian ini merupakan penelitian praexperimental dengan rancangan One Group Pre-Test Post-Test menggunakan satu kelas dengan jumlah 29 siswa sebagai sampel. Penelitian ini dilakukan pretest terlebih dahulu untuk mengukur hasil belajar awal peserta didik, kemudian peserta didik diberi perlakuan berupa pembelajaran berbasis android. Setelah diberi perlakuan dengan menerapkan pembelajaran berbasis android, peserta didik diberikan soal posttest untuk mengukur hasil belajar akhir peserta didik setelah mendapatkan perlakuan.

Penelitian ini dilakukan selama 4 kali pertemuan, dimana setiap pertemuan dilakukan 3 jam pelajaran (3x40 menit) di kelas X IPA A SMA IT Granada Samarinda jadi jumlah waktu pembelajaran yang diberikan kepada siswa adalah 9 jam pelajaran. Dengan rincian 6 jam pelajaran digunakan untuk pembelajaran dan 3 jam pelajaran digunakan untuk pretest-posttest. Pemberian pretest dilakukan pada pertemuan pertama, sedangkan pemberian posttest dilakukan pada pertemuan keempat atau pertemuan terakhir. Pada pertemuan pertama semua siswa hadir sehingga pretest diberikan kepada 29 siswa, dan pada pertemuan terakhir kehadiran siswa juga lengkap, sehingga prestest dan posttest diberikan kepada siswa dengan jumlah yang sama, kemudian selama 4 pertemuan yaitu pertemuan pertama hingga pertemuan keempat pembelajaran di kelas dilakukan dengan mengggunakan produk pembelajaran berbasis android.

Instrumen tes yang digunakan untuk pretest dan posttest berupa soal essai sebanyak 5 soal. Soal tes yang digunakan untuk kemampuan berpikir kritis dan prestasi belajar peserta didik menggunakan soal tes yang sama sehingga nilai prestasi belajar akan berbanding lurus atau sama dengan kemampuan berpikir kritis peserta didik. Sehingga ketika nilai dari hasil belajar juga dapat dilihat kemampuan berpikir kritis yang disesuaikan dengan kriteria jawaban. Nilai hasil belajar siswa merupakan total skor yang yang diperoleh masing-masing siswa dengan skor disesuaikan dengan bobot soal. Siswa diberi waktu 60 menit untuk mengerjakan soal pretest.

Berdasarkan hasil posttest siswa, pada soal nomor satu ada 8 siswa yang menjawab dengan benar dan tepat, 2 siswa tidak mampu menjawab soal, 19 siswa menjawab dengan kurang tepat. Sebesar $63,5 \%$ siswa mengerjakan soal nomer satu dengan benar, dimana soal ini merupakan soal paling sedikit dijawab dengan benar dan tepat oleh siswa. Pada soal nomor dua ada 10 siswa menjawab dengan benar den lengkap, 1 siswa tidak mampu menjawab, 18 siswa menjawab dengan kurang tepat. Sebesar $71,2 \%$ siswa mampu menjawab soal nomor dua dengan tepat. Pada soal nomor tiga ada 13 siswa dapat menjawab dan sisanya menjawab dengan kurang tepat. Soal nomor 3 merupakan soal terbanyak yang dijawab benar oleh siswa, atau sebesar $80,7 \%$ siswa dapat menjawab soal dengan benar. Pada soal nomor empat ada 12 siswa mampu menjawab soal dengan benar dan tetap, 17 siswa menjawab dengan kurang tepat. 
Pada soal nomor empat sebesar $76,7 \%$ siswa dapat menjawab soal dengan benar. Soal nomor lima hanya 8 siswa yang mampu menjawab soal dengan benar, 2 siswa tidak dapat menjawab soal, dan 19 siswa menjawab dengan kurang tepat. Pada soal nomor lima sebesar $70 \%$ siswa sudah mampu menjawab soal dengan benar. Dari lima butir soal yang disajikan, rata-rata siswa kesulitan menjawab pada butir soal nomor satu dan lima. Pada soal nomor satu dan lima, siswa masih belum mampu melakukan indikator membangun keterampilan dasar (Basic Support), sehingga siswa tidak bisa sampai pada indikator menyimpulkan (Inference). Hal ini dikarenakan pada butir soal nomor 1 terdapat bagian menguraikan vector momentum dan siswa tidak mampu menyelesaikannya. Begitupun dengan butir soal nomor lima, dimana siswa tidak mampu menjumlah kecepatan tumbukan dengan tetap memperhatikan vektornya.

Hasil nilai rata-rata prestest peserta didik berdasarkan Tabel 4.1 adalah 27,9 dengan skor terendah 10 dan skor tertinggi 65 . Kemudian pada tabel 4.2 dapat dilihat bahwa dari 29 siswa terdapat 24 siswa atau $82,8 \%$ tergolong kategori kurang sekali, 1 siswa atau $3,4 \%$ tergolong kategori kurang, 4 siswa atau 13,8\% tergolong kategori cukup dan tidak ada siswa dengan kategori baik maupun baik sekali. Hal ini menunjukkan bahwa nilai rata-rata peserta didik pada saat pretest masih sangat kurang dikarenakan peserta didik belum diberikan materi pembelajaran sebelumnya sehingga hanya berfokus pada kemampuan awal siswa saja. Berdasarkan hasil pretest siswa, didapatkan nilai yang termasuk dalam kategori kurang sekali, hal ini dikarenakan siswa belum diajarkan materi tentang impuls dan momentum sehingga masih banyak siswa yang kesulitan dalam mengerjakan soal.

Hasil rata-rata nilai posttest peserta didik adalah 72,4. Berdasarkan hasil rata-rata nilai posttest tersebut, terlihat bahwa saat posttest nilai peserta didik mengalami peningkatan setelah dilakukan pembelajaran berbasis android. Peningkatan nilai rata-rata peserta didik yang diperoleh yaitu sebesar 44,5 . Dengan skor terendah 20 dan skor tertinggi 100. Berdasarkan tabel 4.6 dapat dilihat bahwa skor gain (g) ternormalisasi adalah 0,64. Berdasarkan kriteria dalam kajian teori, nilai 0,64 berada pada rentang $0,7>(\mathrm{g}) \geq 0,3$ sehingga termasuk dalam kategori sedang. Dengan demikian penggunaan pembelajaran berbasis android yang dikembangkan dapat meningkatkan hasil belajar siswa materi impuls dan momentum. Hal tersebut sesuai dengan penelitian dari Siti Muyaroah dan Mega Fajartiah (2017) yang menunjukan bahwa pembelajaran yang menggunakan media pembelajaran berbantuan Adobe Flash CS 6 memiliki nilai hasil belajar yang lebih baik dari pembelajaran konvensional.

Hasil uji efektivitas berupa kemampuan berpikir kritis siswa, hasil posttest yang menunjukkan kemampuan berpikir kritis siswa yang dijadikan sampel penelitian dapat dilihat pada tabel 4.5 menunjukkan data kemampuan berpikir kritis siswa pada pada kelas X IPA A SMA IT Samarinda. Siswa dengan kualifikasi tidak kritis sebesar $10,3 \%$ dengan 3 jumlah siswa. Siswa dengan kualifikasi kurang kritis sebesar 10,3\% dengan 3 jumlah siswa. Siswa dengan kualifikasi cukup kritis sebesar 13,8\% dengan 4 jumlah siswa. Siswa dengan kualifikasi baik sebesar $27,6 \%$ dengan 8 jumlah siswa. Siswa dengan kualifikasi sangat kritis sebesar $38,0 \%$ dengan 11 jumlah siswa.

Berdasarkan indikator penilaian kemampuan berpikir kritis, pada indikator memberikan penjelasan sederhana (Elementary Clarification) diperoleh nilai persentase pretest sebesar $51,2 \%$ dan nilai rata-rata posttest $89,6 \%$ yang termasuk dalam kategori tinggi, hal ini disebabkan pada indikator ini siswa dituntut untuk dapat mengidentifikasi dan mempertimbangkan jawaban yang mungkin untuk suatu permasalahan dari stimulasi yang ditemukan. Sedangkan untuk indikator mengatur strategi dan taktik (Strategi and Tactics) diperoleh nilai persentase pretest sebesar $38 \%$ dan nilai rata-rata posttest $82,4 \%$ yang termasuk dalam kategori tinggi. Pada indikator ini siswa diharapkan dapat memecahkan masalah pada soal dengan berbekal pada pengetahuan yang dapatkan sebelumnya, indikator ini melatih siswa untuk memutuskan suatu tindakan dengan memilih kriteria yang memungkinkan menjadi solusi 
permasalahan. untuk indikator membangun keterampilan dasar (Basic Support) diperoleh nilai persentase pretest sebesar $22,8 \%$ dan nilai rata-rata posttest $73,6 \%$ yang termasuk dalam kategori tinggi. Pada tahap indikator ini siswa dilatih mengumpulkan dan mengolah data, sehingga siswa dapat menggunakan prosedur yang sesuai dengan yang diselidiki pada soal. Pada indikator menyimpulkan (Inference) diperoleh nilai persentase pretest sebesar $0 \%$ dan nilai rata-rata posttest $44 \%$ yang termasuk dalam kategori sedang. Hal ini disebabkan pada saat mengerjakan soal banyak siswa yang tidak bisa menyimpulkan hasil yang diperoleh dari soal tersebut.

Hasil penelitian diperoleh nilai rata-rata pretest sebesar 27,9 dimana nilai rata-rata pretest tersebut termasuk dalam katagori tidak kritis sehingga dapat dikatakan kemampuan berpikir kitis siswa termasuk dalam katagori rendah. Kemudian untuk nilai rata-rata posttest adalah 72,4 dimana nilai rata-rata tersebut termasuk dalam kategori kritis dapat dikatakan nilai rata-rata kemampuan berpikir kritis siswa setelah diberikan perlakuan termasuk dalam kategori tinggi. Ketuntasan belajar dari nilai posttest terdapat 18 siswa yang tuntas mencapai nilai KKM menurut penulis 18 siswa yang tuntas ini dikarenakan pada saat dilakukan kegiatan belajar mengajar mereka terlihat aktif dalam menggunakan media dan memperhatikan apa yang dijelaskan oleh penulis pada saat menjelaskan materi. Tetapi tidak semua siswa terlibat aktif adapun sebagian siswa yang lebih cenderung suka bercanda dengan teman sebangkunya tetapi penulis langsung mengkondisikan kelas, jika terdapat siswa yang kurang memperhatikan, serta 11 siswa yang belum tuntas mencapai nilai KKM dikarenakan pada saat kegiatan belajar mengajar siswa ini jarang hadir pada saat pembelajaran fisika atau tidak membawa andoroid sehingga membuat mereka ketinggalan materi. Terdapat pula satu siswa yang mengerjakan posttest hanya 20 menit sebelum pelajaran berakhir. Keberagaman karakter siswa saat pembelajaran berlangsung menjadi salah satu kendala yang cukup besar bagi peneliti dikarenakan sulit pula dilangsungkan proses belajar-mengajar yang efektif dikelas.

Nilai rata-rata pada X IPA A kemudian dianalisis perbedaan hasil belajar pada aspek kemampuan berpikir kritis siswa. Hasil analisis data dengan media pembelajaran berbasis android ternyata menghasilkan nilai posttest yang signifikan. Harga t-hitung yang lebih besar dari t-tabel untuk $\mathrm{df}=29$ dengan taraf signifikan 0,05 menyebabkan Ha diterima dan Ho ditolak. Berdasarkan hal tersebut telah terbukti bahwa terdapat perbedaan hasil belajar dan kemampuan berpikir kritis siswa sebelum dan sesudah digunakan media pembelajaran berbasis android. Terlihat bahwa media pembelajaran berbasis android yang digunakan disiswa selama melakukan pembelajaran berperan penting dalam meningkatkan hasil belajar dan kemampuan berpikir kritis siswa pada materi impuls dan momentum di kelas $X$ IPA A SMA IT Granada Samarinda, sejalan dengan hasil penelitian yang serupa oleh Saselah, Amir, Riskan (2017) bahwa penggunaan multimedia interaktif berbasis flash membuat siswa mempunyai rasa ingin tahu yang tinggi dan membuat siswa lebih paham tentang konsep abstrak yang dipelajari.

Peningkatan hasil belajar dan kemampuan berpikir kritis siswa membuktikan bahwa media pembelajaran berbasis android berdampak positif bagi cara belajar siswa. Namun diperoleh standar deviasi tinggi sebesar 3,6 menunjukan bahwa peningkatan kemampuan berpikir kritis dan hasil belajar sangat bervariasi. Hal ini mengindikasi tidak seluruh siswa meningkat kemampuan berpikir kritis dan hasil belajarnya setelah menggunakan pembelajaran berbasis android namun sebagian besar dari siswa mengalami peningkatan.

Siswa menggunakan media pembelajaran berbasis android yang membuat mereka menjadi semakin rajin belajar dan sudah mulai mempersiapkan kebutuhan belajar mereka. Hal ini dapat diketahui dari persiapan yang dilakukan oleh peserta didik pada malam hari sebelum mata pelajaran fisika, peserta didik sudah mempersiapkan diri dengan membaca materi pada aplikasi. Selain itu peserta didik juga dapat belajar menggunakan aplikasi dimanapun. Peserta didik juga sudah mulai berusaha mengerjakan soal yang dianggap 
kompleks atau sulut dengan membaca contoh soal yang serupa dengan soal tersebut selanjutnya peserta didik dapat menyelesaikannya. Media pembelajaran berbasis android menuntut siswa turut aktif untuk berpikir, serta membangun pengetahuan sendiri namun masih dibimbing oleh guru sehingga pengetahauan yang diperoleh siswa lebih tertanam dan akan lebih diingat siswa. Penggunaan android saat pembelajaran memberikan kesempatan lebih kepada siswa untuk mencari dan menemukan fakta, konsep, dan prinsip sehingga pembelajaran di kelas menjadi lebih optimal. Namun masih ditemukan berbagai kesulitan saat pembelajaran seperti koneksi internet yang tidak selalu baik saat pembelajaran dilangsungkan, beberapa siswa yang kurang berkonsentrasi karena lebih tertarik pada fitur games di aplikasi dibandingkan dengan materi ajar.

Pengembangan aplikasi ini masih sederhana, untuk itu peneliti merekomendasikan untuk pengembangan aplikasi agar versi selanjutnya lebih baik lagi. Hal yang perlu dikembangkan lagi adalah pengembangan materi lebih lanjut berpacu pada kurikulum 2013 sehingga tidak hanya dapat digunakan sebagai penujang pembelajaran namun juga dapat melatih keterampilan berpikir siswa. Penambahan konten-konten menarik dan penggunakan bahasa yang komunikatif dirasa perlu untuk menambah motivasi siswa. Pengembangan aplikasi untuk materi fisika yang lain bahkan mata pelajaran lain pun juga dapat dilakukan.

\section{PENUTUP}

Berdasarkan hasil penelitian dan analisis data yang telah dilakukan di SMA IT Granada Samarinda di kelas X IPA A, dapat disimpulkan bahwa, pembelajaran pada materi impuls dan momentum menghasilkan produk berupa aplikasi berbasis mobile learning bernama elearning physics yang dapat diakses melalui smartphone. Aplikasi berbasis web ini bersifat online sehingga memerlukan internet dalam penggunaannya. Kualitas pembelajaran berbasis mobile learning pada platform android untuk siswa SMA IT Granada Samarinda yang telah dikembangkan berdasarkan penilaian ahli materi dan ahli media adalah valid digunakan karena telah memenuhi kelayakan isi dan kelayakan konstruk. Pada uji efektivitas diperoleh kemampuan berpikir kritis siswa setelah menggunakan media pembelajaran berbasis android dengan program Adobe Flash CS 6 terdapat peningkatan dengan nilai ratarata 72,4 dalam kategori kritis. Pada hasil belajar siswa materi impuls dan momentum melalui pretest dan posttest dengan pembelajaran berbasis android dengan Adobe Flash CS 6 melalui uji $\mathrm{N}-$ Gain dengan hasil 0,64 dalam katagori sedang.

Adapun saran pemanfaatan dan pengembangan produk lebih lanjut adalah sebagai berikut: (1) Diharapkan penggunaan media pembelajaran yang telah dikembangkan ini dapat dimanfaatkan secara optimal lagi sehingga hasil kelayakan dan keefektifitasan media pembelajaran lebih meningkat. Baik peneliti selanjutnya sebaiknya mengembangkan suatu media pembelajaran dengan materi lebih banyak lagi dan lebih bervariasi lagi. Dari segi pengunduahan lebih baik diunggah pada google playstore sehingga lebih mempermudah user dalam penggunaannya. (2) Bagi siswa sebaiknya mempertahankan semangat belajar fisika dan meningkatkan kerjasama antarsiswa dalam mendiskusikan materi fisika yang belum dipahami.

\section{DAFTAR PUSTAKA}

Amalia, R. D. (2016). Pengembangan Media Pembelajaran Education Mobile Berbasis Android pada Mata Pelajaran IPA Fisika Kelas VIII di MTs Al-Asror Patemon Kecamatan Gunung Patai Kota Semarang. Skripsi. Universitas Negeri Semarang.

Astra, I. M. (2012). Aplikasi Mobile Learning Fisika dengan Menggunakan Adobe Flash sebagai Media Pembelajaran Pendukung. Jurnal Pendidikan Dan Kebudayaan, 18(2), 174-180.

Badan Standar Nasional Pendidikan. (2006). Kurikulum Tingkat Satuan Pendidikan. Jakarta: Departemen Pendidikan Nasional 
Darmayoga, I. W., Lasmawan, I. W., \& Marhaeni, A. A. I. N. (2013). Pengaruh Implementasi Metode Mind Mapping Terhadap Hasil Belajar Ips Ditinjau Dari Minat Siswa Kelas Iv Sd Sathya Sai Denpasar. PENDASI: Jurnal Pendidikan Dasar Indonesia, 3(1), 1-11.

Ena, O. T. (2011). Membuat Media Pembelajaran Interaktif dengan Piranti Lunak Presentasi. Yogyakarta: Universitas Sanata Dharma Yogyakarta, 2(1), 1-8.

Febrianto, F., Rais, M., \& Nurmila, N. (2018). Analisis Penerapan Media Pembelajaran Prezi Terhadap Hasil Belajar Siswa Kelas $X$ TPHP pada Mata Pelajaran Pengendalian Mutu dalam Proses Pengolahan Di SMK Negeri 3 Takalar. Jurnal Pendidikan Teknologi Pertanian, 2(1), 47-56.

Fisher, Alec. (2001). Critical Thinking. An Introduction. Britain: Cambridge University Press.

Hanum, N. S. (2013). Keefetifan e-learning sebagai media pembelajaran (studi evaluasi model pembelajaran e-learning SMK Telkom Sandhy Putra Purwokerto). Jurnal Pendidikan Vokasi, 3(1), 90-102.

Linggasari, Y. (2015). Tim Evaluasi Kurikulum 2013 Temukan Dua Masalah Utama. Diakses tanggal 30 Juni 2020 (http://www.cnnindonesia.com/nasional/20 150122221521-20-26717/timevaluasikurikulum-2013-temukan-dua-masalahutama/).

Mulya, A. (2015). Guru Belum Melek Teknologi. Harian Nasional (25 Juni 2015). HIm. 1. Diakses tanggal 30 Juni 2020 (http://www.harnas.co/ 2015/06/25/guru belum-melekteknologi)

Muyaroah, S \& Mega, F. (2017). Pengembangan Media Pembelajaran Berbasis Android dengan menggunakan Aplikasi Adobe Flash CS 6 pada Mata Pelajaran Biologi. Innovative Journal of Curriculum and Educational Technology, 6(2), 22-26.
Nurtantio \& Syarif. (2013). Kreasikan Animasimu dengan Adobe Flash dalam Membuat Sistem Multimedia Interaktif. Yogyakarta: Andi Publisher.

Pertiwi. (2016). "Pengaruh Model Project Based Learning Terhadap Peningkatan Hasil Belajar Fisika Pada Materi Pesawat Sederhana Siswa Kelas VIII SMP Negeri 32 Makassar". Skripsi, Universitas Negeri Alauddin Makassar.

Saselah, Y. R., Amir, M., \& Riskan, M. (2017). Pengembangan Multimedia Interaktif Berbasis Adobe Flash CS6 Professional Pada Pembelajaran Kesetimbangan Kimia. Jurnal Kimia Dan Pembelajaran Kimia, 2(2), 80-89.

Sudjana, N \& Ibrahim. (2012). Penelitian dan Penilain Pendidikan. Bandung: Sinar Baru Algesindo.

Yudhi, M. (2013). Media Pembelajaran. Jakarta: Ciputat Pers.

Yustyan, S., Widodo, N., \& Pantiwati, Y. (2015). Peningkatan Kemampuan Berpikir Kritis dengan Pembelajaran Berbasis Scientific Approach Siswa Kelas X SMA Panjura Malang. Jurnal Pendidikan Biologi Indonesia, 1(2), 240-254. 